\title{
The Effects of China's Development Projects on Political Accountability
}

\author{
Szu-Ning Ping ${ }^{1}$, Yi-Ting Wang ${ }^{1 *}($ D $)$ and Wen-Yang Chang ${ }^{2}$ (D) \\ ${ }^{1}$ Department of Political Science, National Cheng Kung University, Taiwan and ${ }^{2}$ Department of Diplomacy, National \\ Chengchi University, Taiwan \\ *Corresponding author. E-mail: yitingw@mail.ncku.edu.tw
}

(Received 12 September 2019; revised 5 May 2020; accepted 25 June 2020; first published online 2 December 2020)

\begin{abstract}
The literature on the relationship between foreign aid and institutions has found that the effects of aid vary across different donor characteristics and delivery mechanisms. This article focuses on China's resourcerelated development projects, which have been considered controversial due to the relative lack of conditionality. By distinguishing between vertical and horizontal dimensions of political accountability, the study finds that China's resource-related projects are particularly detrimental to the accountability of recipient countries' horizontal (legislative and judicial) institutions. These projects are often delivered to resource-rich countries, in the form of packaging access to resources and infrastructure construction, to improve China's own energy access. Local officials may be tempted to weaken horizontal institutions so that the projects can be implemented quickly. Nevertheless, these projects have little effect on vertical accountability, as China has less intention and capacity to fundamentally restrain electoral competition in recipient countries.
\end{abstract}

Keywords: China's development projects; political accountability; natural resources; state-owned enterprises

Many recent studies have examined the impact of foreign development assistance on institutions in recipient countries. As Dietrich and Wright (2013) summarize, some studies group development flows with other types of 'unearned income' and find that foreign aid may undermine democratic governance by encouraging rent seeking and corruption, allowing leaders to buy support and decreasing citizens' demands (for example, Ahmed 2012; Bräutigam and Knack 2004; Bueno de Mesquita and Smith 2010; Djankov, Montalvo, and Reynal-Querol 2008; Knack 2004; Moss, Pettersson and Van de Walle 2006).

However, other studies emphasize the variations in donors' preferences and delivery mechanisms, arguing that under certain conditions - such as when funding conditionality is credibly imposed, when donors have a preference for democracy or when aid programs are adequately tailored - foreign aid is effective at helping democratic institutions develop and survive (Bermeo 2011; Dietrich and Wright 2014; Dunning 2004; Finkel, Pérez-Liñán and Seligson 2007; Scott and Steele 2011).

With its rapid economic growth, China has become a crucial donor of development flows in recent decades. However, as a non-traditional donor that has abstained from the Organisation for Economic Co-operation and Development (OECD) Development Assistance Committee (DAC), its economic assistance is considered controversial. Both Western donors and recipient countries have concerns about China's motivation and potentially disruptive effects on recipients. For example, in 2018, then-US National Security Advisor John Bolton criticized China's predatory 
foreign aid, especially the related programs in Africa (Holland and Wroughton 2018). In the same year, Malaysia officially declined infrastructure-related projects funded by China, which could potentially lead to the country's bankruptcy (Erickson 2018). Nevertheless, many developing countries prefer Chinese financing because it is associated with few political conditions due to China's non-interference principle, and tends to emphasize infrastructure projects and productive activities (Alves 2013; Furukawa 2018).

China's economic assistance is substantially different from conventional aid. Based on the literature, the features of non-conditionality and no preferences for democracy are expected to prevent its assistance from improving democratic institutions. Despite criticism that they have potentially adverse effects, limited cross-sectional quantitative research has explored how and why China's development projects affect the political institutions of recipient countries. In this article, we focus on Chinese development programs related to natural resources, such as energy generation and mining. We examine how the features of these programs influence the political accountability of recipient countries. In contrast to previous studies that mainly rely on a binary or one-dimensional definition of democracy, we distinguish between horizontal and vertical aspects of political accountability. Horizontal accountability refers to the capacity of horizontal institutions - including legislatures, judicial branches and ombudsmen - to impose constraints on executive power. Vertical accountability concerns electoral restraints on the executive. Both aspects are key mechanisms of political control and are at the core of good governance: vertical accountability is the defining element of democratic governance, on which many good consequences of democracy depend, while weakened horizontal institutions may lead to executive abuse of power and autocratization processes. Separating these two aspects allows us to more rigorously examine how these unique financial flows have differential impacts on institutions.

Utilizing time-series cross-sectional data that cover the period from 2000 to 2014 and about 130 developing countries, we find that China's resource-related programs erode political institutions in recipient countries. However, the negative effect is only found for horizontal accountability. We argue that this is mainly due to the strategic goal and delivery mechanism of these programs. China provides development assistance largely in the form of official investment in energy production and infrastructure building through state-owned enterprises (SOEs) to fulfill its energy demands. Political systems with weak checks and balances are convenient for China's resource-driven aid strategy as well as officials in recipient countries. Such unconditional financial flows benefit incumbents more directly and can be used to compromise horizontal institutions. This funding from China is also attractive to officials aiming for economic growth. Incumbents may be tempted to circumvent horizontal institutions so that construction can be implemented quickly. We also use an instrumental variable setup and the generalized synthetic control (GSC) approach to verify the causal relationship.

In addition to contributing to the literature on the external factors of regime changes, our results offer insights into the conditions under which foreign economic assistance can lead to adverse consequences. Improving governance is at the core of development efforts, and a more systematic understanding of how Chinese aid strategy influences political accountability is required.

\section{Foreign Aid and Political Institutions}

Studies investigating the relationship between aid and political institutions have provided a mixed picture. Many scholars argue that aid is likely to undermine institutions and democratic governance. These studies highlight the similarity between aid and other types of non-tax revenue, such as natural resources. They argue that governments that are less dependent on internal sources of revenue tend to be less accountable to their citizens and have fewer incentives to establish effective institutions (Ahmed 2012; Bräutigam and Knack 2004; Bueno de Mesquita and Smith 2010; Djankov, Montalvo and Reynal-Querol 2008; Moss, Pettersson and Van de Walle 2006). Aid inflows also release political leaders' revenue constraints, freeing up more resources to patronize 
or repress potential oppositions without incurring political costs, which may result in the stabilization of dictatorships (Morrison 2007; Remmer 2004). Additionally, aid tends to encourage rent seeking and corruption, particularly when donors impose few conditionalities on recipients (Asongu and Nwachukwu 2016; Djankov, Montalvo and Reynal-Querol 2008; Hodler and Raschky 2014; Knack 2004).

In contrast to this pessimistic view, some recent studies criticize comparisons between aid and natural resources as inaccurate. Given aid's relative infungibility and conditionality, it can improve the prospects of democratic change (Altincekic and Bearce 2014; Bermeo 2016b). Other studies focus on the heterogeneity of donors and their delivery mechanisms, and suggest that foreign assistance can strengthen democratic institutions under certain circumstances. For example, if conditionalities are credibly imposed, recipient governments have more incentives to comply with aid goals and implement institutional reforms (Dunning 2004; Knack 2001). When aid allocation is conditional on recipients' democratic performance, democratic change is more likely to occur (Kersting and Kilby 2014). Furthermore, democracy assistance is particularly helpful in strengthening institutions when it is carefully targeted at specific sectors (Dietrich and Wright 2014; Jones and Tarp 2016; Scott and Steele 2011). Bermeo (2011) shows that aid from democratic donors tends to be associated with democratic transitions because they are more likely to have a preference for democracy and intend to reward recipient countries that are moving toward democracy.

Following research that disaggregates aid based on donor preferences and delivery mechanisms, we focus on Chinese assistance, particularly resource-related programs, and investigate its effects on political institutions. With its well-known non-interference policy, there seems to be no indication that China intentionally supports authoritarianism abroad. However, it does not co-operate with traditional donors or adhere to the principles established by them (Mawdsley, Savage and Kim 2014; Strange et al. 2013). The most notorious feature is the lack of conditionality to promote political reform and good governance. Based on previous studies, the lack of both conditionality and preferences for democracy promotion lead to the expectation that Chinese economic engagement has negative, or at least non-positive, effects on institutions.

Nevertheless, the claims find mixed support, and little cross-sectional quantitative evidence has been provided (Dreher et al. 2018). Some studies express concerns that Chinese aid is more likely to be subject to capture and undermine governance (Tull 2006; Wako 2018), while some find no evidence supporting this negative association (Bader and Daxecker 2015; Bräutigam 2009). Focusing on one and several African countries, Brazys, Elkink and Kelly (2017) and Isaksson and Kotsadam (2018), respectively, find that Chinese projects are associated with increased perceptions of local-level corruption. Although corruption can be considered a symptom of weakening institutions, it is not clear whether the findings can be extrapolated to the macro level or to other recipient countries. With regard to overall regime type, scholars have not reached a consensus on whether China's economic assistance undermines democracy and stabilizes authoritarianism (Bader 2015a; Bader 2015b; Jenkins 2010).

\section{China's Resource-Related Projects and Political Accountability}

Chinese development flows take many different forms, including humanitarian aid, medical aid, debt relief and volunteer programs (Alves 2013). Among the different types, we focus on projects related to natural resource development (China's resource-related projects, hereafter CRPs). ${ }^{1}$ These projects are provided by China largely with the expectation of meeting its energy demands. China is not the only country using aid to increase its economic benefits. As a rapidly growing economy requiring a massive amount of energy (State Council (PRC) 2012), however, China

\footnotetext{
${ }^{1}$ As an anonymous reviewer reminded us, only a small subset of Chinese development financing meets the DAC definition of 'aid'. Therefore, we refrain from referring to these official financial flows as aid.
} 


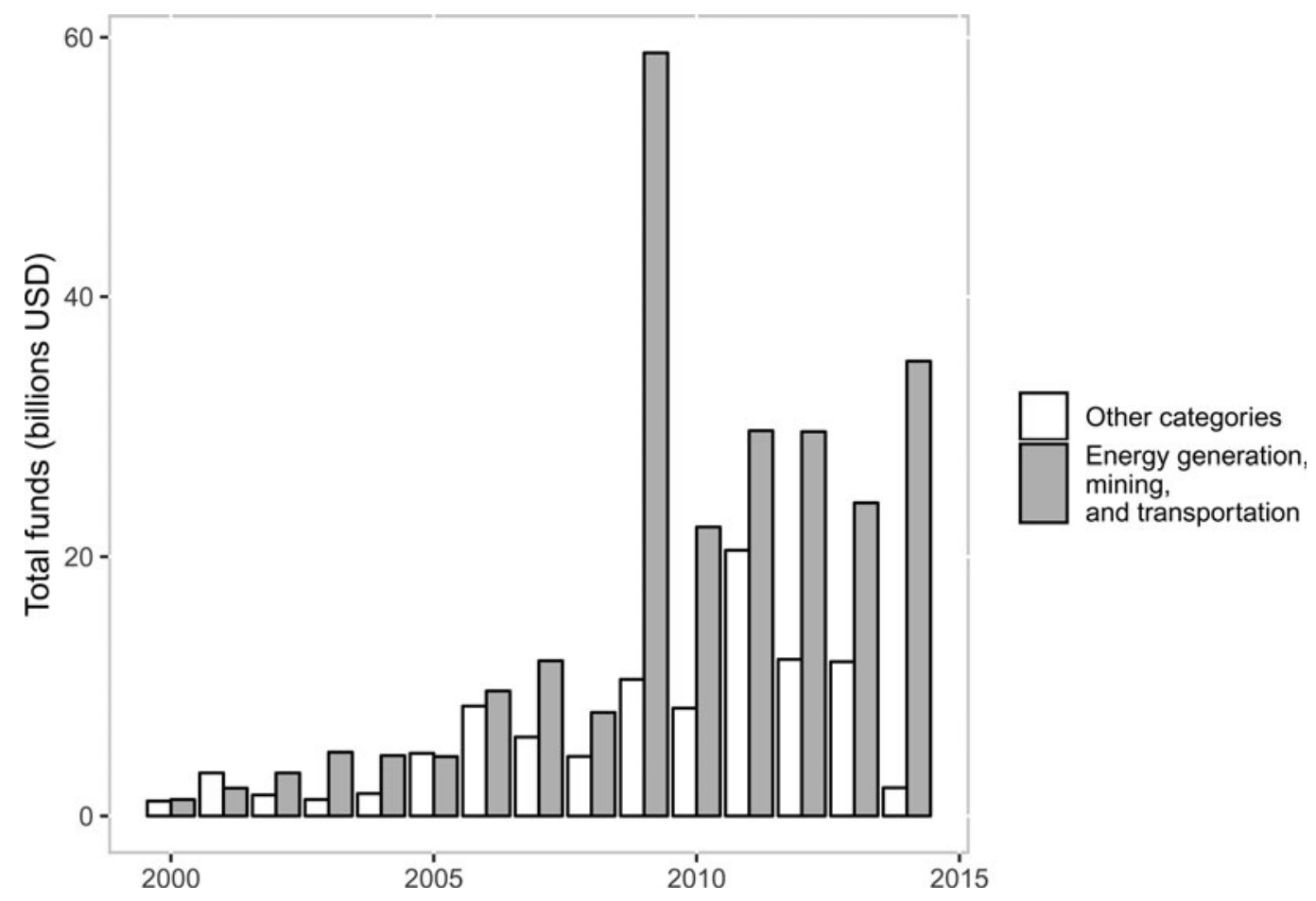

Figure 1. Financial flows provided by China, 2000-2014

differs from other donors in the resource-driven nature of its assistance programs (Alves 2013). China has been become a net importer of oil products since 1993 (Leung, Li and Low 2011). It provides economic assistance to resource-abundant countries for a return in natural resources (Buckley et al. 2007; Dreher et al. 2018). For instance, China sometimes receives a contractual portion of oil production (called 'share oil') as part of its aid package.

Another feature of CRPs is the packaging of access to resources and infrastructure projects, which has become a common practice of China in many resource-rich countries (Bader and Daxecker 2015; Brazys, Elkink and Kelly 2017). The funding for roads, railways, ports and power generation facilities improves local resource production and transportation, and allows China to secure the supply of resources (Alden and Alves 2009). Although not all Chinese assistance projects are related to resources, according to AidData's Global Chinese Official Finance Dataset (Dreher et al. 2017), projects classified in the categories of energy generation, mining and transportation accounted for 72 per cent of the total amount provided by China from 2000 to 2014. As shown in Figure 1, this percentage has significantly increased since the 2010s.

These projects are largely delivered through Chinese SOEs, which in 2005 controlled 83 per cent of the country's outbound investment flows. Despite a recent gradual decrease, SOEs still monopolize several sectors, including oil and gas, telecommunications and construction (Kolstad and Wiig 2012; Wang and Zhao 2017). As a national policy instrument, SOEs implement China's foreign assistance as well as seek profits. This is not a typical delivery mechanism of OECD development assistance, which does not classify investment as a form of foreign aid.

Previous studies on the relationship between foreign aid and institutions mostly utilize conventional measures that combine different features of a regime into one-dimensional indices. However, as recent research has suggested (see Coppedge et al. 2011), democratic/non-democratic governance involves multiple features, and aid may have a differential impact on different institutions (Doucouliagos 2019). We focus on political accountability institutions as our dependent 
variable, and distinguish between vertical and horizontal accountability. The power to hold politicians accountable is fundamental to representative democracy. Both aspects of accountability are key mechanisms of political control. They have distinct roles in subjecting the executive to electoral competition and constraining the executive, and may be influenced differently by foreign projects, as Dietrich and Wright (2014) suggest.

Vertical accountability concerns electoral restraints on the executive branch of the government (O’Donnell 1998; Mechkova, Lührmann and Lindberg 2019). Incumbents have to respond to voters' preferences in order to be re-elected. Citizens are better able to exert electoral control over politicians when certain conditions are met: suffrage is extensive, main office holders are selected through regular competitive elections without fraud, and opposition parties can freely organize and compete for power (Dahl 1973). Horizontal accountability refers to the capacity of horizontal institutions - such as legislatures, judicial branches and ombudsmen - to impose constraints on executive power (O'Donnell 1998, 119). When these institutions have instruments with which to question, investigate and exercise oversight of the executive, abuse of power by the government is more likely to be prevented (Fish 2006; Persson, Roland and Tabellini 1997). Additionally, if horizontal institutions are strengthened, the wrongdoings of government officials, such as corruption, are more likely to be exposed and punished, significantly increasing the costs of such behavior (Kolstad and Wiig 2016; McMann et al. 2019). Overall, vertical accountability is the key element of electoral democracy, while horizontal accountability is related to, but more fundamental than, the concept of institutional quality.

\section{Horizontal Accountability}

We propose that CRPs have different effects on horizontal and vertical accountability. Due to the unique features of these programs as described above, they are expected to be particularly harmful to horizontal institutions in recipient countries for several reasons.

First, prior studies have demonstrated that conditionality and carefully targeted projects are crucial mechanisms through which the detrimental effects of aid can be deterred and institutional reforms can be encouraged. However, as a highly corrupt autocracy itself, China is indifferent to using aid to improve democratic governance in recipient countries. Without conditions imposed on aid disbursement, leaders are better able to exploit aid for patronage (Hout 2007; Molenaers, Dellepiane and Faust 2015). Additionally, CRPs are provided largely due to China's high energy demand. To continuously satisfy such a demand, economic support has to be consistently provided, and the threat of stopping aid if recipients do not meet governance conditions would not be credible. Dietrich and Wright $(2013,61)$ posit that foreign funding may 'damage the development of effective checks and balances in recipient countries by reinforcing the power of the executive at the expense of legislative constraints' when the assistance is mainly directed to the executive. According to Bader (2015b), Chinese aid benefits incumbent governments more directly than Western aid. In some cases, it is even based on requests from recipient governments (Dreher et al. 2016; Isaksson and Kotsadam 2018), ${ }^{2}$ which further intensifies the tendency to use unconditional flows to buy off potential legislative opposition and reinforce executive power.

Secondly, CRPs are likely to amplify the potential adverse effects of natural resources on the quality of institutions in recipient countries. General regulations and constraints are unfavorable to Chinese SOEs seeking privileges in host countries. Resource-driven investments require host countries that can award contracts for oil drilling or allow preferential access for the procurement of certain goods. During negotiations for resource access, political systems with fewer veto players are expected to grant agreements more expeditiously and with more flexibility. Horizontal institutions that can exert considerable constraints are able to restrict leaders' abilities to make

\footnotetext{
${ }^{2}$ Request-based aid is proposed by the recipients; donors decide whether to approve it after reviewing the proposal. Hambantota Port in Sri Lanka is a typical example.
} 
arbitrary policies (Bodea, Garriga and Higashijima 2019) and favor particular investors. An opaque institutional environment in which policies can be passed without detailed scrutiny is therefore preferred by the Chinese government. As the aid provider has an interest in weakened horizontal institutions, politicians in recipient countries may be induced to dismantle institutions that regulate the use of natural resources (Ross 2001) in order to attract assistance and obtain rents. Politicians who seek more exclusive and discretionary rights to allocate state assets are likely to weaken institutions that constrain them (Ross 2001).

One reason for the attractiveness of CRPs is the packaging of access to resources and infrastructure buildings. The funding of development projects creates a 'get-rich-quick' mentality that is similar to commodity booms (Ross 2001, 30). Under such conditions, as Mazzuca's (2013) analysis of resource windfalls suggests, incumbents are tempted to remove checks and balances to allow excessive short-term consumption. Although aid inflows are not identical to commodity booms, CRPs may lead to a similar tendency. The massive provision of infrastructure mirrors China's own successful development experience (Alves 2013; Démurger 2001; Ravallion 2009), and receiving these projects seems to signify the country is on the right growth trajectory. Because loans typically do not need to be repaid for several years, mega infrastructure projects are tempting to politicians faced with electoral competition. To quickly facilitate such construction initiatives, incumbents may strive to dominate the decision-making process at the expense of legislatures. In the name of national development, even actors capable of imposing scrutiny are reluctant to raise objections.

Overall, political systems with weak checks and balances are convenient for China's resourcedriven aid strategy. To attract funds and fulfill the expectation of national development more quickly, politicians may be tempted to circumvent horizontal accountability institutions. In addition, due to the non-conditionality feature, the executive has ample resources it can use to compromise the oversight capacity of horizontal institutions.

China's projects in Ecuador have demonstrated this tendency. China has provided Ecuador with billions of dollars in loans, most of which has been used for infrastructure and energy projects. In return, China has received oil as loan collateral. In the construction of the Coca-Codo Sinclair hydroelectric dam, top Ecuadorean officials pressed ahead with the project despite warnings and overlooked environmental and engineering problems; the officials responsible for monitoring the project appear to have been bought off so the project could proceed (Casey and Krauss 2018). Chinese projects in several other places, including Kenya's Standard Gauge Railway and Sri Lanka's Hambantota Port, were also rushed to approval despite contracts that were opaque, feasibility reports that raised concerns and officials' circumvention of regulations (Abi-Habib 2018; Marsh 2019). To systematically verify this tendency, we formulate the following hypothesis.

Hypothesis 1: China's resource-related development projects have a negative impact on horizontal accountability in recipient countries.

One may be concerned that the proposed negative relationship is due to China selectively providing assistance to countries already with weak institutions. However, Dreher and Fuchs (2015) and Wako (2018) find that China's aid allocation is independent of recipients' institutional quality. In the analyses, we also utilize instrumental strategies to determine the causal direction.

One may also wonder whether China would have an interest in preventing the weakening of checks and balances in order to provide its SOEs with more predictable and transparent investment environments. In CRPs, Chinese SOEs have the dual responsibilities of aid delivery and foreign direct investment that seeks profits. Indeed, investments may be adversely affected by executive expropriation in systems where horizontal institutions are incapable of checking unilateral executive decision making (Jensen 2008; Jensen, Malesky and Weymouth 2014). However, unlike other foreign private investors, Chinese SOEs are funded by the state (Nordensvard, Urban and Mang 2015; Ru 2018) and are thus more accepting of risks (Buckley et al. 2007; 
Kolstad and Wiig 2012). State endorsement helps protect SOEs from deprivation by the host government and makes them more resilient to weak institutions. State-backed SOEs can bribe local officials to weaken regulations and win contracts. For example, a former Hong Kong government official, Chi Ping Patrick Ho, attempted to bribe politicians in Chad to waive fines for environmental violations and maintain an unfair competitive advantage for CEFC China Energy, a Shanghai-based conglomerate (Marsh 2018). Since a majority of CRPs are implemented by Chinese SOEs (as shown in the next section), which have no interest in improving the governance of recipient countries, the negative impacts of CRPs on horizontal institutions are expected to be further reinforced.

\section{Vertical Accountability}

Concerning vertical accountability, we hypothesize that the adverse effects of CRPs tend to be insubstantial for several reasons. First, in the post-Cold War era, once elections with some competition have been established, it is difficult for them to be entirely abolished. Mechkova, Lührmann and Lindberg (2017) note that elections are high-profile events and can be more easily observed by the international community and media. Violating such highly visible institutions incurs higher legitimacy costs (Schedler 2013). The blatant manipulation of electoral results or the widespread or harsh intimidation of the opposition are likely to trigger protests (Bunce and Wolchik 2010). Furthermore, because democratic promoters emphasize elections, holding multiparty elections helps rulers attract more resources from Western donors (Kim and Kroeger 2017; Levitsky and Way 2010; Reinsberg 2015). The literature on the recent pattern of 'autocratization' (Lührmann and Lindberg 2019) shows that in the last decade, improvements in democratic governance have mostly been in the area related to elections (Lührmann et al. 2018; Mechkova, Lührmann and Lindberg 2017). Bermeo (2016a) and Coppedge (2017) find that dramatic democratic breakdowns have become rarer; autocratization through the gradual concentration of power in the executive and the weakening of checks and balances has become more common.

Secondly, and more importantly, the packaging of access to resources and infrastructure projects has mixed effects on vertical accountability. On the one hand, improving a country's infrastructure can lead to economic growth and better living conditions (Bougheas, Demetriades and Mamuneas 2000; Esfahani and Ramírez 2003), which are important preconditions for popular demands for more political participation. Habiyaremye (2013) finds that China's infrastructure-for-resource strategy in Africa has led to higher growth rates than other forms of assistance. When aid promotes economic development, it helps improve electoral competition in the long term (Kersting and Kilby 2014).

On the other hand, rulers may also use infrastructure projects to appease and repress citizens (Altincekic and Bearce 2014). With regard to appeasement, the provision of public goods improves the welfare of a large population of citizens and thereby diminishes their desire for regime change (Bueno de Mesquita and Smith 2010). China's direct financing of energy and transportation construction, which constitute public goods without taxation, is expected to pacify disaffected citizens. Regarding repression, although transportation facilities help citizens organize demonstrations, they also allow leaders to send troops and suppress revolts more easily. Development projects may also replace money that governments would have spent on infrastructure, thus freeing funds for other uses, including repression. Overall, we argue that it is more difficult for incumbents to terminate electoral institutions, and China's infrastructure-for-resource strategy has mixed effects on popular political mobilization. Therefore, CRPs are expected to have only a minimal influence on vertical accountability. We propose the following hypothesis.

Hypothesis 2: China's resource-related development projects do not have a significant impact on vertical accountability in recipient countries. 


\section{Data and Measures}

\section{Dependent Variable}

To explore the effects of China's resource-related assistance on different aspects of political accountability, we mainly rely on the data provided by the Varieties of Democracy (V-Dem) project (dataset version 8). The project distinguishes among various aspects of institutions and governance, each measured using several detailed and concrete indicators. ${ }^{3}$ We utilize the V-Dem horizontal accountability index as an indication of legislative and judicial control over the executive. The index is formed by point estimates from a Bayesian factor analysis model, which includes the extent to which the national legislature/parliament is capable of questioning, investigating and exercising oversight of the executive, particularly when the executive is involved in potentially illegal or unethical activities. The index also combines whether the executive complies with judicial decisions and whether the judiciary can act independently to prevent the executive abuse of power. Instead of formal rules, the index focuses on actual practices of these horizontal institutions, which are more likely to be affected by inflows of development projects.

We also use the checks and balances variable provided by the Database of Political Institutions (DPI) (Cruz, Keefer and Scartascini 2016) as an alternative dependent variable. It captures the number of partisan and institutional veto players. However, because it includes a component of vertical accountability (whether members of the legislature are appointed by the executive), it is less suitable for analysis in this article.

To verify whether CRPs have less significant effects on the electoral aspect of accountability, we use the V-Dem vertical accountability index. The index is also formed by point estimates from a Bayesian factor analysis model. It combines whether: elections are free and fair, the chief executive is directly or indirectly selected through elections, suffrage is extensive, and political parties can form and operate freely. The Polity IV (Marshall, Gurr and Jaggers 2017) political competition index, which measures the competitiveness and inclusiveness of political participation, is also used as an alternative variable.

\section{Independent Variable}

The key explanatory variable is based on data collected by AidData's Global Chinese Official Finance Dataset (Dreher et al. 2017). The dataset documents officially financed Chinese projects to other countries during 2000-2014. ${ }^{4}$ Because our theoretical arguments are based on the features of CRPs, we distinguished between projects related to energy generation, mineral mining, and transportation and other projects. For the former, resource-related flows, we aggregate all projects in the categories of 'Energy Generation and Supply' (3-digit CRS sector code: 230), 'Industry, Mining, Construction' (320) and 'Transport and Storage' (210) to create country-year level variables. ${ }^{5}$ For the latter, we aggregate projects in all other categories to verify that the expected relationships between China's assistance and accountability can be mainly attributed to the features of its resource-driven strategy. Following the literature (for example, Bermeo 2016b; Dietrich and Wright 2014), the logged value of (one plus) funds per capita and funds as a share of gross national income (GNI) are calculated to reduce right skew. In addition, as Dietrich and Wright (2014) suggest, to ensure that the measures capture the current level of

\footnotetext{
${ }^{3}$ Appendix A contains more detailed information on the V-Dem project and a discussion of its methodological limitations.

${ }^{4}$ It includes both projects that meet the OECD criteria of official development assistance (ODA) and those without development intent. Because the Chinese government does not release project-level data, the data are estimated by triangulating publicly available information from various sources.

${ }^{5}$ Information on more detailed classifications of subsectors is not available. Among all 4,312 projects documented in the dataset, 874 are classified in these three categories; the funding for these projects accounts for 72 per cent of the total funds provided by China.
} 
inflows rather than large fluctuations in a given year, the measures are averaged over 3 years $(t, t-1$, and $t-2)$.

To verify whether the involvement of SOEs further reinforces the negative association between CRPs and horizontal accountability, we distinguish between projects implemented by Chinese SOEs and those executed by other agencies. Of all 4,312 projects in the dataset, AidData has information on the implementing agencies for 1,242 of them (494 resource related, 748 other categories). We check the features of these agencies to classify projects as either involving Chinese SOEs or not. ${ }^{6}$ Consistent with previous descriptions, CRPs are largely delivered through their SOEs. Of the 1,242 projects for which we have information on the implementing agencies, 83 per cent of resource-related projects involve Chinese SOEs, while SOEs implement only 43 per cent of projects in other categories. For a recipient in a given year, inflows from these two types are aggregated separately. Similarly, 3-year averages of funds per capita and funds as a share of GNI are log-transformed.

To determine the causal direction, we employ an instrumental variable suggested by Dreher et al. (2017): the interaction of Chinese steel production in a given year with the recipient country's probability of receiving CRPs. As Dreher et al. (2017) point out, China's annual production of steel is closely related to its capacity to supply development projects, because the Chinese government considers steel a strategic commodity, and some of its steel surplus is used as inputs for aid. The data on China's annual steel production during 2000-2014 are taken from the National Material Capabilities dataset (Singer, Bremer and Stuckey 1972). We lag the data for an additional year to allow for a delay between domestic overproduction and international projects. Each recipient country's probability of receiving CRPs is calculated as the fraction of years from 2000 to 2014 in which the country received positive amounts of Chinese financing in the three relevant categories. Chinese steel production only varies over time and is exogenous to the institutional accountability of recipient countries. One might be concerned that the probability of receiving CRPs may directly affect accountability. As Dreher et al. $(2016,2017)$ explain, since the probability of receiving funds varies only across countries, and country fixed effects are also included in the regressions, the interaction between the probability and an exogenous variable results in an exogenous instrument (see Bun and Harrison 2019).

\section{Controls}

We include several potential confounders as control variables. To estimate the effects of China's financing and conventional aid separately, we control for countries' inflows of official development assistance (ODA). Because the Chinese financial amounts documented by AidData most closely represent commitment amounts rather than net disbursements, to facilitate comparison, we use OECD data on ODA commitments. ${ }^{7}$ Consistent with the measures of China's financing, 3-year averages of ODA per capita and ODA as a share of GNI are calculated and log-transformed.

Since political accountability is a key feature of representative democracy, we follow previous studies on regime transition and survival to select the remaining controls. The literature has suggested economic development as an important factor of democratic transitions and consolidation (for example, Boix and Stokes 2003; Przeworski and Limongi 1997). To account for a country's general level of development, we include logged GDP per capita in purchasing power parity

\footnotetext{
${ }^{6}$ Our classification differs slightly from that of AidData. We code an agency as a Chinese SOE if it is a subsidiary of a giant $\mathrm{SOE}$, or if there is a specific section on its website promoting the manifesto of the Chinese Communist Party. Among agencies originally classified as non-SOEs by AidData, we identify eighteen of them as SOEs. Analyses based on both classifications generate consistent results.

${ }^{7}$ In Tables B.1 and B.2, we include analyses with ODA net disbursements, and the results are consistent. The ODA measure does not include Chinese aid flows. As the AidData codebook indicates, the Chinese government has opted out of international reporting systems.
} 
terms. An indicator of GDP growth rate is also included, as economic performance has been shown to be strongly associated with the likelihood of regime breakdown (Gasiorowski 1995; Treisman 2015). Data on both variables are taken from the World Development Indicators (WDI). Rulers can use natural resource rents to consolidate their control; such rents thus have negative effects on the openness and competitiveness of political participation (Ross 2015). We use Ross and Mahdavi's (2015) measures of per capita net oil and gas export value to calculate natural resource rents.

Studies on regime diffusion find that countries tend to adopt and sustain democracy/autocracy if more countries in the same region are democratic/authoritarian (Gleditsch and Ward 2006; Miller 2015). Therefore, we include a measure of annual average Polity scores in a given politicogeographic region. To account for a country's previous experience with democracy, we follow Gerring et al. (2005) and construct a measure of democracy stock based on Polity scores.

Appendix Table A.1 reports the descriptive statistics of these variables. Excluding countryyears classified as 'high income' in the WDI dataset, the analysis covers the period from 2000 to 2014 for approximately 130 countries in the regions of Africa, the Middle East, Asia and the Pacific, Latin America and the Caribbean, and Central and Eastern Europe. To address omitted variable bias concerns, we include country and year fixed effects in the time-series crosssectional models. In all models, independent variables are lagged by 1 year. Each model is run with robust standard errors to account for the issues of heteroscedasticity and autocorrelation.

In addition to ordinary least squares (OLS) and two-stage least-squares (2SLS) regressions with two-way fixed effects, we also use the GSC approach proposed by Xu (2017) to examine the robustness of the results. Fixed effects models rest on the 'parallel-trend' assumption, which holds that without CRPs (treatment), institutional accountability would have been the same on average between countries receiving and not receiving assistance. The GSC method is designed to address the possibility that the outcomes may be driven by some unobserved timevarying confounders between treated and non-treated cases. Based on information of non-treated cases, this method imputes 'counterfactuals' that incorporate the unobserved confounders for treated countries, from which we can better estimate the causal effects of Chinese financing on accountability. In this approach, the independent variable is modeled as a binary treatment. We classify a country as 'treated' if it received positive amounts of Chinese financing in the three relevant categories. Because resource-related projects tend to involve fixed assets, a country is considered treated from the first year in which it received funding.

\section{Analysis}

Tables 1 and 2 show the estimated effects of CRPs on horizontal accountability. The measures of Chinese and conventional aid as a share of GNI are employed in Table 1, and models with measures of aid per capita are presented in Table 2. In both tables, the dependent variable of Models 1-6 is the V-Dem horizontal accountability index. Model 1 only includes the measure of CRPs, while Chinese projects of other categories and conventional ODA are controlled in Model 2. The results show that Chinese projects in the categories of energy, mining and transportation have consistent negative effects on horizontal accountability, either measured as a percentage of GNI or per capita, while Chinese funding of other categories does not have significant effects. Model 3 replicates Model 2 with 2SLS regressions, where the first-stage instrument is the interaction of Chinese steel production and the probability of receiving CRPs. The weak identification tests show that the instrument explains a sufficient amount of variance in Chinese resource-related flows, particularly the per capita measure. Model 4 includes additional controls. The results of Models 3 and 4 are generally consistent with those of Model 2. ${ }^{8}$ Based on Model 2

\footnotetext{
${ }^{8}$ In Tables 1 and 2, the coefficients for CRPs in Model 3 (2SLS) are greater than the corresponding coefficients in Model 2 (OLS). This may be because the financial values of CRPs, particularly as shares of GNI, are more subject to short-term
} 
Table 1. Regression estimates of the effect of CRPs (\% GNI) on horizontal accountability

\begin{tabular}{|c|c|c|c|c|c|c|c|}
\hline DV & $\begin{array}{c}\text { Horizontal } \\
\text { accountability } \\
1 \\
\text { OLS }\end{array}$ & $\begin{array}{c}\text { Horizontal } \\
\text { accountability } \\
2 \\
\text { OLS }\end{array}$ & $\begin{array}{c}\text { Horizontal } \\
\text { accountability } \\
3 \\
2 \text { SLS }\end{array}$ & $\begin{array}{c}\text { Horizontal } \\
\text { accountability } \\
4 \\
\text { OLS }\end{array}$ & $\begin{array}{c}\text { Horizontal } \\
\text { accountability } \\
5 \\
\text { OLS }\end{array}$ & $\begin{array}{c}\Delta \text { Horizontal } \\
\text { accountability } \\
6 \\
\text { OLS }\end{array}$ & $\begin{array}{c}\text { Checks } \\
7 \\
\text { OLS }\end{array}$ \\
\hline $\begin{array}{l}\text { In China's flows \% GNI } \\
\text { (resource-related) } \\
\text { ln China's flows \% GNI } \\
\text { (other categories) } \\
\text { Polity }\end{array}$ & $\begin{array}{l}-0.0899^{\star \star} \\
(0.0417)\end{array}$ & $\begin{array}{l}-0.0779 * * \\
(0.0392) \\
0.0120 \\
(0.0345)\end{array}$ & $\begin{array}{l}-0.248^{\star \star} \\
(0.106) \\
-0.000171 \\
(0.0178)\end{array}$ & $\begin{array}{l}-0.0782^{\star \star} \\
(0.0385) \\
-0.00904 \\
(0.0332)\end{array}$ & $\begin{array}{l}-0.0680^{\star \star} \\
(0.0312) \\
0.00643 \\
(0.0295) \\
0.0388^{\star \star \star} \\
(0.00840)\end{array}$ & $\begin{array}{l}-0.0314^{\star \star} \\
(0.0157) \\
-0.0168 \\
(0.0157)\end{array}$ & $\begin{array}{l}-0.238^{\star \star} \\
(0.0949) \\
-0.185 \\
(0.191)\end{array}$ \\
\hline $\begin{array}{l}\text { Polity } \times \text { In China's } \\
\quad \text { flows } \\
\% \text { GNI } \\
\text { (resource-related) }\end{array}$ & & & & & $\begin{array}{l}0.00484 \\
(0.00551)\end{array}$ & & \\
\hline In ODA \% GNI & & $\begin{array}{l}0.0691^{\star \star \star} \\
(0.0263)\end{array}$ & $\begin{array}{l}0.0656^{\star \star \star} \\
(0.0223)\end{array}$ & $\begin{array}{l}0.0891^{\star \star \star} \\
(0.0331)\end{array}$ & $\begin{array}{l}0.0777^{\star \star \star} \\
(0.0293)\end{array}$ & $\begin{array}{l}0.0252^{\star \star} \\
(0.0120)\end{array}$ & $\begin{array}{l}0.523^{\star \star \star} \\
(0.183)\end{array}$ \\
\hline Regional avg. polity & & $\begin{array}{l}0.0979^{\star \star \star} \\
(0.0264)\end{array}$ & $\begin{array}{l}0.0875^{\star \star \star} \\
(0.0131)\end{array}$ & $\begin{array}{l}0.0705^{\star \star \star} \\
(0.0234)\end{array}$ & $\begin{array}{l}0.0278^{\star} \\
(0.0142)\end{array}$ & $\begin{array}{l}-0.00645 \\
(0.00660)\end{array}$ & $\begin{array}{l}-0.0119 \\
(0.161)\end{array}$ \\
\hline In GDP per capita & & & & $\begin{array}{l}0.178 \\
(0.126)\end{array}$ & $\begin{array}{l}0.241^{\star \star} \\
(0.113)\end{array}$ & $\begin{array}{l}0.00573 \\
(0.0570)\end{array}$ & $\begin{array}{l}-0.344 \\
(0.356)\end{array}$ \\
\hline GDP growth & & & & $\begin{array}{l}-0.00532^{\star *} \\
(0.00224)\end{array}$ & $\begin{array}{l}-0.00638^{\star \star \star} \\
(0.00192)\end{array}$ & $\begin{array}{l}-0.00520^{\star \star} \\
(0.00206)\end{array}$ & $\begin{array}{l}0.0117^{\star} \\
(0.00603)\end{array}$ \\
\hline Oil export per capita & & & & $\begin{array}{l}-0.000037^{\star} \\
(0.00002)\end{array}$ & $\begin{array}{l}-0.000043^{\star *} \\
(0.000019)\end{array}$ & $\begin{array}{l}-0.000018^{\star} \\
(0.0000096)\end{array}$ & $\begin{array}{l}0.000043 \\
(0.000051)\end{array}$ \\
\hline Gas export per capita & & & & $\begin{array}{l}-0.000022 \\
(0.000039)\end{array}$ & $\begin{array}{l}-0.000019 \\
(0.000038)\end{array}$ & $\begin{array}{l}-0.00003 \\
(0.000021)\end{array}$ & $\begin{array}{l}-0.00022 \\
(0.00015)\end{array}$ \\
\hline Democracy stock & & & & $\begin{array}{l}-0.000722 \\
(0.000744)\end{array}$ & $\begin{array}{l}-0.00129^{\star} \\
(0.000686)\end{array}$ & $\begin{array}{l}-0.00103^{\star \star \star} \\
(0.000345)\end{array}$ & $\begin{array}{l}-0.000188 \\
(0.00236)\end{array}$ \\
\hline LDV & & & & & & $\begin{array}{l}-0.214^{\star \star \star} \\
(0.0357)\end{array}$ & \\
\hline Constant & $\begin{array}{l}0.166^{\star \star \star} \\
(0.0282)\end{array}$ & $\begin{array}{l}-0.125 \\
(0.0815)\end{array}$ & & $\begin{array}{l}-1.565 \\
(1.065)\end{array}$ & $\begin{array}{l}-2.096^{\star \star} \\
(0.947)\end{array}$ & $\begin{array}{l}-0.0463 \\
(0.481)\end{array}$ & $\begin{array}{l}4.645 \\
(3.042)\end{array}$ \\
\hline Country FE & $\mathrm{V}$ & V & $\mathrm{v}$ & v & $\mathrm{v}$ & $\mathrm{V}$ & $\mathrm{v}$ \\
\hline Year FE & $\mathrm{V}$ & $\mathrm{V}$ & $\mathrm{V}$ & $\mathrm{V}$ & $\mathrm{V}$ & V & $\mathrm{V}$ \\
\hline $\mathrm{N}$ & 1,709 & 1,658 & 1,378 & 1,496 & 1,496 & 1,388 & 1,349 \\
\hline Countries & 141 & 139 & 137 & 127 & 127 & 126 & 125 \\
\hline Log likelihood & 114.9 & 266.2 & 123.9 & 324.3 & 412.5 & 787.2 & $-1,797.0$ \\
\hline adj. R-sq (within) & 0.034 & 0.110 & -0.137 & 0.091 & 0.191 & 0.111 & 0.033 \\
\hline $\begin{array}{l}\text { Cragg-Donald Wald F } \\
\text { Kleibergen-Paap F }\end{array}$ & & & $\begin{array}{l}27.7 \\
17.99\end{array}$ & & & & \\
\hline
\end{tabular}

Note: all independent variables are lagged one year. Robust standard errors in brackets. ${ }^{*} p<0.1 ;{ }^{\star \star} p<0.05 ;{ }^{* \star \star} p<0.01$. 
Table 2. Regression estimates of the effect of CRPs (per capita) on horizontal accountability

\begin{tabular}{|c|c|c|c|c|c|c|c|}
\hline DV & $\begin{array}{c}\text { Horizontal } \\
\text { accountability } \\
1 \\
\text { OLS }\end{array}$ & $\begin{array}{c}\text { Horizontal } \\
\text { accountability } \\
2 \\
\text { OLS }\end{array}$ & $\begin{array}{c}\text { Horizontal } \\
\text { accountability } \\
3 \\
2 S L S\end{array}$ & $\begin{array}{c}\text { Horizontal } \\
\text { accountability } \\
4 \\
\text { OLS }\end{array}$ & $\begin{array}{c}\text { Horizontal } \\
\text { accountability } \\
5 \\
\text { OLS }\end{array}$ & $\begin{array}{c}\Delta \text { Horizontal } \\
\text { accountability } \\
6 \\
\text { OLS }\end{array}$ & $\begin{array}{c}\text { Checks } \\
7 \\
\text { OLS }\end{array}$ \\
\hline $\begin{array}{l}\text { In China's flows per } \\
\text { capita }\end{array}$ & $-0.0522^{\star \star \star}$ & $-0.0469^{\star \star \star}$ & $-0.0948^{\star \star \star}$ & $-0.0452^{\star \star \star}$ & $-0.0460^{\star \star \star}$ & $-0.0146^{\star \star}$ & $-0.107^{\star \star}$ \\
\hline $\begin{array}{l}\text { (resource-related) } \\
\text { In China's flows per } \\
\text { capita }\end{array}$ & $(0.0182)$ & $\begin{array}{l}(0.0159) \\
0.00627\end{array}$ & $\begin{array}{l}(0.0264) \\
0.000291\end{array}$ & $\begin{array}{l}(0.0160) \\
-0.0156\end{array}$ & $\begin{array}{l}(0.0142) \\
-0.00824\end{array}$ & $\begin{array}{l}(0.00679) \\
-0.00860\end{array}$ & $\begin{array}{l}(0.0449) \\
-0.120^{\star}\end{array}$ \\
\hline $\begin{array}{l}\text { (other categories) } \\
\text { Polity }\end{array}$ & & $(0.0199)$ & $(0.00771)$ & $(0.0164)$ & $\begin{array}{l}(0.0133) \\
0.0380^{\star \star \star} \\
(0.00804)\end{array}$ & $(0.00627)$ & $(0.0675)$ \\
\hline $\begin{array}{l}\text { Polity } \times \text { In China's flows } \\
\text { per capita } \\
\text { (resource-related) }\end{array}$ & & & & & $\begin{array}{l}0.00245 \\
(0.00215)\end{array}$ & & \\
\hline In ODA per capita & & $\begin{array}{l}0.125^{\star \star \star} \\
(0.0361)\end{array}$ & $\begin{array}{l}0.0954^{\star \star \star} \\
(0.0174)\end{array}$ & $\begin{array}{l}0.124^{\star \star \star} \\
(0.0349)\end{array}$ & $\begin{array}{l}0.0954^{\star \star \star} \\
(0.0295)\end{array}$ & $\begin{array}{l}0.0296^{\star \star} \\
(0.0126)\end{array}$ & $\begin{array}{l}0.506^{\star \star \star} \\
(0.159)\end{array}$ \\
\hline Regional avg. polity & & $\begin{array}{l}0.0913^{\star \star \star} \\
(0.0245)\end{array}$ & $\begin{array}{l}0.0810^{\star \star \star} \\
(0.0123)\end{array}$ & $\begin{array}{l}0.0643^{\star \star \star} \\
(0.0216)\end{array}$ & $\begin{array}{l}0.0226^{\star} \\
(0.0131)\end{array}$ & $\begin{array}{l}-0.00715 \\
(0.00670)\end{array}$ & $\begin{array}{l}-0.0369 \\
(0.160)\end{array}$ \\
\hline In GDP per capita & & & & $\begin{array}{l}0.118 \\
(0.120)\end{array}$ & $\begin{array}{l}0.196^{\star} \\
(0.110)\end{array}$ & $\begin{array}{l}-0.00332 \\
(0.0557)\end{array}$ & $\begin{array}{l}-0.669^{\star} \\
(0.357)\end{array}$ \\
\hline GDP growth & & & & $\begin{array}{l}-0.00476^{\star \star} \\
(0.00215)\end{array}$ & $\begin{array}{l}-0.00588^{\star \star \star} \\
(0.00188)\end{array}$ & $\begin{array}{l}-0.00492^{\star \star} \\
(0.00209)\end{array}$ & $\begin{array}{l}0.0137^{\star \star} \\
(0.00600)\end{array}$ \\
\hline Oil export per capita & & & & $\begin{array}{l}-0.000029 \\
(0.00002)\end{array}$ & $\begin{array}{l}-0.000039^{\star \star} \\
(0.000017)\end{array}$ & $\begin{array}{l}-0.000016^{*} \\
(0.0000093)\end{array}$ & $\begin{array}{l}0.000051 \\
(0.000055)\end{array}$ \\
\hline Gas export per capita & & & & $\begin{array}{l}-0.000026 \\
(0.00004)\end{array}$ & $\begin{array}{l}-0.000018 \\
(0.00004)\end{array}$ & $\begin{array}{l}-0.000031 \\
(0.000022)\end{array}$ & $\begin{array}{l}-0.00024 \\
(0.00015)\end{array}$ \\
\hline Democracy stock & & & & $\begin{array}{l}-0.000833 \\
(0.000691)\end{array}$ & $\begin{array}{l}-0.00150^{\star \star} \\
(0.000686)\end{array}$ & $\begin{array}{l}-0.00104^{\star \star \star} \\
(0.000339)\end{array}$ & $\begin{array}{l}-0.000174 \\
(0.00234)\end{array}$ \\
\hline LDV & & & & & & $\begin{array}{l}-0.224^{\star \star \star} \\
(0.0349)\end{array}$ & \\
\hline Constant & $\begin{array}{l}0.167^{\star \star \star} \\
(0.0280)\end{array}$ & $\begin{array}{l}-0.443^{\star \star \star} \\
(0.136)\end{array}$ & & $\begin{array}{l}-1.322 \\
(1.026)\end{array}$ & $\begin{array}{l}-1.902^{\star \star} \\
(0.929)\end{array}$ & $\begin{array}{l}-0.0202 \\
(0.464)\end{array}$ & $\begin{array}{l}6.625^{\star \star} \\
(2.913)\end{array}$ \\
\hline Country FE & v & v & $\mathrm{v}$ & v & v & v & v \\
\hline Year FE & V & V & v & V & V & V & V \\
\hline $\mathrm{N}$ & 1,709 & 1,705 & 1,419 & 1,505 & 1,505 & 1,396 & 1,357 \\
\hline Countries & 141 & 141 & 139 & 127 & 127 & 126 & 125 \\
\hline Log likelihood & 123.9 & 232.4 & 129.3 & 341.8 & 430.4 & 776.1 & $-1,802.2$ \\
\hline $\begin{array}{l}\text { adj. } R^{2} \text { (within) } \\
\text { Cragg-Donald Wald } \mathrm{F} \\
\text { Kleibergen-Paap } \mathrm{F}\end{array}$ & 0.044 & 0.159 & $\begin{array}{l}-0.031 \\
71.44 \\
60.29\end{array}$ & 0.124 & 0.221 & 0.112 & 0.042 \\
\hline
\end{tabular}


in Table 1, the effect of a 50 per cent increase in the financial values of CRPs is roughly equivalent to the effect of the same amount of decrease in conventional ODA (or a 0.3-point decrease in regional average Polity scores), and is associated with a reduction of 0.03 on the horizontal accountability scale, which roughly has a mean $=0$ and standard deviation $=1$.

To verify whether the effects of China's funding vary across regime types, in Model 5 we include the Polity score and its interaction term with CRPs. The coefficients for CRPs retain significant negative estimates, while the interaction shows no significant influence. That is, CRPs are detrimental to horizontal institutions in both democratic and non-democratic regimes. Model 6 uses the annual change in country $i$ 's horizontal accountability index score from year $t-1$ to $t$ as the dependent variable. In Model 6, the lagged dependent variable (LDV) is included as a proxy for omitted variables and controls for the possibility of temporal correlation. ${ }^{9}$ The dependent variable of Model 7 is the DPI checks and balances index. The results of both Tables 1 and 2 show that CRPs are also negatively associated with the alternative measure of horizontal accountability.

Table 3 shows the same analyses with different measures of vertical accountability as the dependent variable. The measures include the V-Dem vertical accountability (Models 1-4 and 6-9) and Polity IV political competition indices (Models 5 and 10). Models 1-5 use the share of GNI as the measure of foreign financial flows, while Models 6-10 employ the per capita measures. Models 1 and 6 are OLS regressions with CRPs, Chinese assistance of other categories and ODA as independent variables. Models 2 and 7 replicate Models 1 and 6 with 2SLS regressions. Models 3-5 and 8-10 incorporate additional controls. In Models 4 and 9, the dependent variable is the annual change in vertical accountability, and the LDV is also taken into account. Across these models with different specifications, the coefficients for indicators of CRPs are negative but not significant, and are generally less than half of the corresponding coefficients reported in Tables 1 and 2, which use horizontal accountability as the dependent variable. The results are consistent with our theoretical expectation: CRPs tend to be harmful to horizontal accountability institutions, but their effects on electoral competition and participation are less clear.

Appendix Tables B.1-B.8 present additional robustness checks. Tables B.1 and B.2 include analyses with ODA net disbursements as the measure of conventional aid. To verify whether the results depend on particular data transformation, Table B.3 includes models using nonlogged measures, logged financial values without divided by population and the number of Chinese development projects in relevant categories as the key independent variables. Table B.4 includes models with different time-series specifications. The models in Table B.5 are based on imputed data. Across these robustness checks, the results are generally consistent with those in Tables 1-3. The dependent variables in Tables B.6 and B.7 are composing indicators of the horizontal and vertical accountability indices, respectively. The results show that the associations reported in Tables 1-3 are not driven by only a few components. In Models 1 and 2 in Table B.8, we aggregate all Chinese projects, and in Models 3 and 4 we only account for projects of other categories. The negative effects of these other-category projects on horizontal accountability are less significant. The results are consistent with our theoretical expectation that the negative association between China's development projects and accountability is mainly based on features of its resource-driven strategy.

\footnotetext{
fluctuations than the instrument. The variance in the raw measures of CRPs is roughly four times that of the predicted values used in the second-stage regressions of 2SLS.

${ }^{9}$ Model 6 in Tables 1 and 2 and Models 4 and 9 in Table 3 include the LDV. These models are in the form of $\Delta Y_{t}=\alpha_{0}+$ $\alpha_{1} Y_{t-1}+\beta_{1} X_{t-1}+\varepsilon_{t}$, and are equivalent to $Y_{t}=\alpha_{0}^{*}+\alpha_{1}^{*} Y_{t-1}+\beta_{1} X_{t-1}+\varepsilon_{t}$ (index score in time $t$ as the dependent variable, and LDV included in the right-hand side) (De Boef and Keele 2008). The DVs of horizontal and vertical accountability are moderately trended, and thus the analysis should account for LDV. However, for a limited sample covering only 15 years, models with country fixed effects along with LDV can lead to bias (Nickell 1981). Therefore, we do not include the LDV in all models.
} 
Table 3. Regression estimates of the effect of CRPs on vertical accountability

\begin{tabular}{|c|c|c|c|c|c|c|c|c|c|c|}
\hline DV & $\begin{array}{c}\text { Vertical } \\
1 \\
\text { OLS }\end{array}$ & $\begin{array}{c}\text { Vertical } \\
2 \\
2 S L S\end{array}$ & $\begin{array}{c}\text { Vertical } \\
3 \\
\text { OLS }\end{array}$ & $\begin{array}{c}\Delta \text { Vertical } \\
4 \\
\text { OLS }\end{array}$ & $\begin{array}{c}\text { Competition } \\
5 \\
\text { OLS }\end{array}$ & $\begin{array}{c}\text { Vertical } \\
6 \\
\text { OLS }\end{array}$ & $\begin{array}{c}\text { Vertical } \\
7 \\
2 S L S\end{array}$ & $\begin{array}{c}\text { Vertical } \\
8 \\
\text { OLS }\end{array}$ & $\begin{array}{c}\Delta \text { Vertical } \\
9 \\
\text { OLS }\end{array}$ & $\begin{array}{c}\text { Competition } \\
10 \\
\text { OLS }\end{array}$ \\
\hline $\begin{array}{l}\text { In China's flows \% GNI } \\
\text { (resource-related) }\end{array}$ & $\begin{array}{l}-0.0364 \\
(0.0403)\end{array}$ & $\begin{array}{l}-0.117 \\
(0.101)\end{array}$ & $\begin{array}{l}-0.0388 \\
(0.0404)\end{array}$ & $\begin{array}{l}-0.0160 \\
(0.0146)\end{array}$ & $\begin{array}{l}-0.0193 \\
(0.100)\end{array}$ & & & & & \\
\hline $\begin{array}{l}\text { In China's flows \% GNI } \\
\text { (other categories) }\end{array}$ & $\begin{array}{l}-0.0240 \\
(0.0503)\end{array}$ & $\begin{array}{l}-0.0317^{\star} \\
(0.0187)\end{array}$ & $\begin{array}{l}-0.0238 \\
(0.0598)\end{array}$ & $\begin{array}{l}0.0139 \\
(0.0295)\end{array}$ & $\begin{array}{l}-0.0787 \\
(0.120)\end{array}$ & & & & & \\
\hline In ODA \% GNI & $\begin{array}{l}0.0719^{\star} \\
(0.0415)\end{array}$ & $\begin{array}{l}0.0396^{\star} \\
(0.0226)\end{array}$ & $\begin{array}{l}0.0702 \\
(0.0475)\end{array}$ & $\begin{array}{l}0.0361^{*} \\
(0.0195)\end{array}$ & $\begin{array}{l}-0.121 \\
(0.146)\end{array}$ & & & & & \\
\hline $\begin{array}{l}\text { In China's flows per capita } \\
\text { (resource-related) }\end{array}$ & & & & & & $\begin{array}{l}-0.0261 \\
(0.0173)\end{array}$ & $\begin{array}{l}-0.0443 \\
(0.0276)\end{array}$ & $\begin{array}{l}-0.0272 \\
(0.0175)\end{array}$ & $\begin{array}{l}-0.00962 \\
(0.00599)\end{array}$ & $\begin{array}{l}0.0145 \\
(0.0579)\end{array}$ \\
\hline $\begin{array}{l}\text { In China's flows per capita } \\
\text { (other categories) }\end{array}$ & & & & & & $\begin{array}{l}-0.000370 \\
(0.0196)\end{array}$ & $\begin{array}{l}-0.00836 \\
(0.00711)\end{array}$ & $\begin{array}{l}-0.00670 \\
(0.0243)\end{array}$ & $\begin{array}{l}0.00665 \\
(0.0106)\end{array}$ & $\begin{array}{l}-0.0473 \\
(0.0474)\end{array}$ \\
\hline In ODA per capita & & & & & & $\begin{array}{l}0.100^{\star *} \\
(0.0435)\end{array}$ & $\begin{array}{l}0.0672^{\star \star \star} \\
(0.0207)\end{array}$ & $\begin{array}{l}0.102^{\star \star} \\
(0.0416)\end{array}$ & $\begin{array}{l}0.0364^{*} \\
(0.0199)\end{array}$ & $\begin{array}{l}0.0841 \\
(0.123)\end{array}$ \\
\hline Regional avg. polity & $\begin{array}{l}0.120^{\star \star \star} \\
(0.0398)\end{array}$ & $\begin{array}{l}0.111^{\star \star \star} \\
(0.0167)\end{array}$ & $\begin{array}{l}0.124^{\star \star} \\
(0.0497)\end{array}$ & $\begin{array}{l}0.0232^{\star} \\
(0.0130)\end{array}$ & $\begin{array}{l}0.220^{\star \star} \\
(0.110)\end{array}$ & $\begin{array}{l}0.114^{\star \star \star} \\
(0.0393)\end{array}$ & $\begin{array}{l}0.109^{\star \star \star} \\
(0.0163)\end{array}$ & $\begin{array}{l}0.119^{\star \star} \\
(0.0492)\end{array}$ & $\begin{array}{l}0.0220^{\star} \\
(0.0128)\end{array}$ & $\begin{array}{l}0.220^{\star} \\
(0.112)\end{array}$ \\
\hline In GDP per capita & & & $\begin{array}{l}0.0550 \\
(0.149)\end{array}$ & $\begin{array}{l}0.00384 \\
(0.0852)\end{array}$ & $\begin{array}{l}-0.197 \\
(0.377)\end{array}$ & & & $\begin{array}{l}0.0108 \\
(0.145)\end{array}$ & $\begin{array}{l}-0.0209 \\
(0.0838)\end{array}$ & $\begin{array}{l}-0.181 \\
(0.359)\end{array}$ \\
\hline GDP growth & & & $\begin{array}{l}-0.000678 \\
(0.00423)\end{array}$ & $\begin{array}{l}0.0000317 \\
(0.00366)\end{array}$ & $\begin{array}{l}0.00578 \\
(0.00551)\end{array}$ & & & $\begin{array}{l}-0.000438 \\
(0.00408)\end{array}$ & $\begin{array}{l}0.000147 \\
(0.00359)\end{array}$ & $\begin{array}{l}0.00643 \\
(0.00541)\end{array}$ \\
\hline Oil export per capita & & & $\begin{array}{l}-0.0000085 \\
(0.000025)\end{array}$ & $\begin{array}{l}-0.000011 \\
(0.000013)\end{array}$ & $\begin{array}{l}0.0000061 \\
(0.000076)\end{array}$ & & & $\begin{array}{l}-0.0000031 \\
(0.000026)\end{array}$ & $\begin{array}{l}-0.00001 \\
(0.000011)\end{array}$ & $\begin{array}{l}0.000031 \\
(0.000076)\end{array}$ \\
\hline Gas export per capita & & & $\begin{array}{l}-0.000021 \\
(0.000025)\end{array}$ & $\begin{array}{l}-0.00001 \\
(0.000022)\end{array}$ & $\begin{array}{l}-0.00003 \\
(0.000065)\end{array}$ & & & $\begin{array}{l}-0.000024 \\
(0.000024)\end{array}$ & $\begin{array}{l}-0.000012 \\
(0.000021)\end{array}$ & $\begin{array}{l}-0.000041 \\
(0.000062)\end{array}$ \\
\hline Democracy stock & & & $\begin{array}{l}-0.000639 \\
(0.000804)\end{array}$ & $\begin{array}{l}-0.000810^{\star \star} \\
(0.000351)\end{array}$ & $\begin{array}{l}-0.000170 \\
(0.00225)\end{array}$ & & & $\begin{array}{l}-0.000728 \\
(0.000757)\end{array}$ & $\begin{array}{l}-0.000831^{\star \star} \\
(0.000352)\end{array}$ & $\begin{array}{l}-0.0000837 \\
(0.00226)\end{array}$ \\
\hline LDV & & & & $\begin{array}{l}-0.255^{\star \star \star} \\
(0.0344)\end{array}$ & & & & & $\begin{array}{l}-0.259^{\star \star \star} \\
(0.0343)\end{array}$ & \\
\hline Constant & $\begin{array}{l}0.107 \\
(0.110)\end{array}$ & & $\begin{array}{l}-0.383 \\
(1.296)\end{array}$ & $\begin{array}{l}0.00929 \\
(0.709)\end{array}$ & $\begin{array}{l}7.967^{\star \star} \\
(3.177)\end{array}$ & $\begin{array}{l}-0.115 \\
(0.155)\end{array}$ & & $\begin{array}{l}-0.231 \\
(1.227)\end{array}$ & $\begin{array}{l}0.156 \\
(0.665)\end{array}$ & $\begin{array}{l}7.341^{\star \star} \\
(2.971)\end{array}$ \\
\hline Country FE & v & v & v & $\mathrm{v}$ & v & v & v & v & v & v \\
\hline Year FE & $\mathrm{v}$ & $\mathrm{v}$ & $\mathrm{v}$ & v & v & v & v & $\mathrm{v}$ & v & v \\
\hline $\mathrm{N}$ & 1,658 & 1,378 & 1,496 & 1,388 & 1,456 & 1,705 & 1,419 & 1,505 & 1,396 & 1,464 \\
\hline Countries & 139 & 137 & 127 & 126 & 127 & 141 & 139 & 127 & 126 & 127 \\
\hline Log likelihood & 77.67 & 159.3 & 60.80 & 357.9 & $-1,481.3$ & 75.44 & 140.0 & 69.70 & 363.2 & $-1,502.5$ \\
\hline adj. $R^{2}$ (within) & 0.133 & 0.066 & 0.124 & 0.110 & 0.049 & 0.154 & 0.094 & 0.142 & 0.110 & 0.053 \\
\hline Cragg-Donald Wald F & & 27.703 & & & & & 71.443 & & & \\
\hline Kleibergen-Paap F & & 17.99 & & & & & 60.29 & & & \\
\hline
\end{tabular}

Note: all independent variables are lagged one year. Robust standard errors in brackets. ${ }^{*} p<0.1 ;{ }^{* \star} p<0.05 ;{ }^{\star \star *} p<0.01$. 

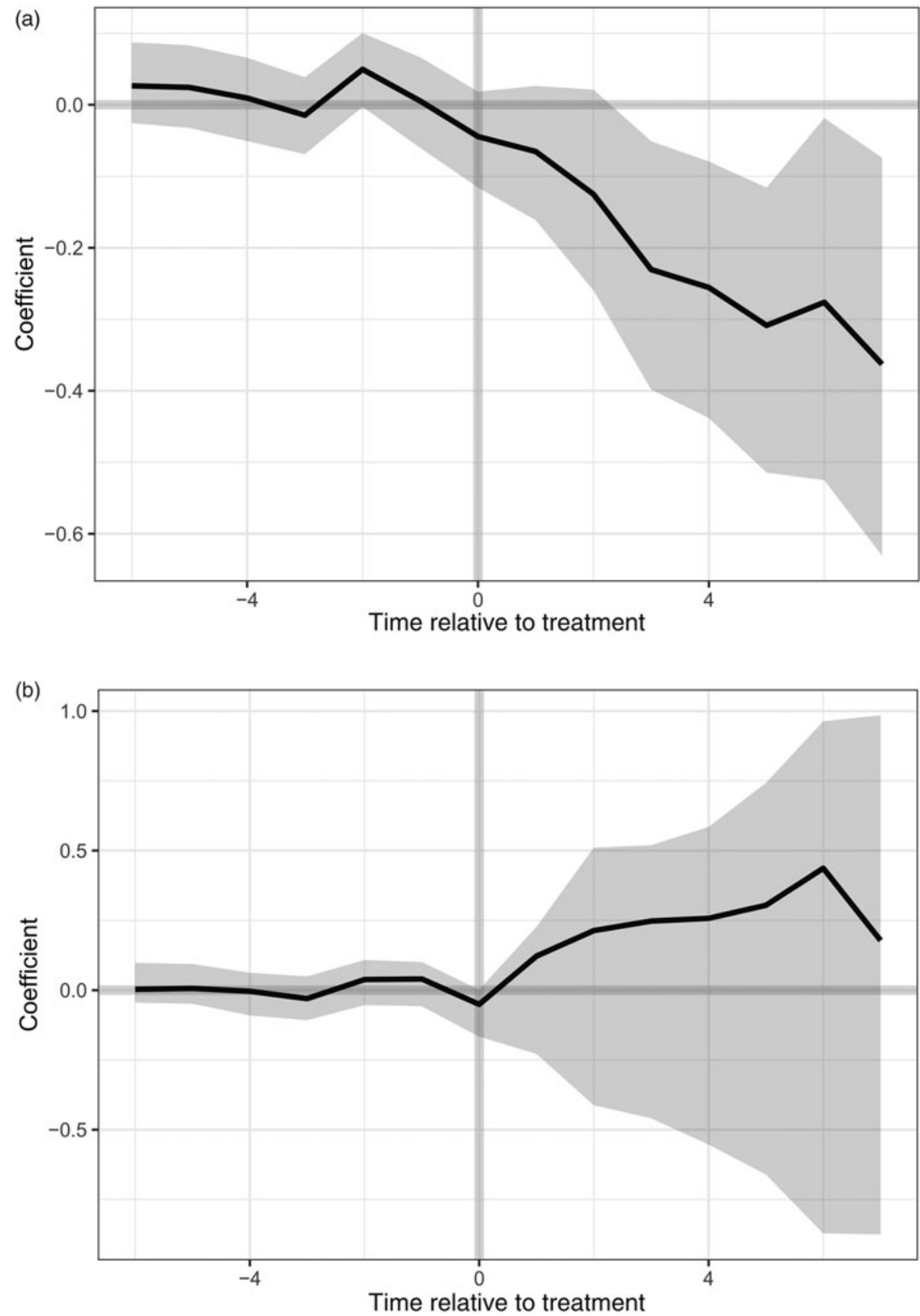

Figure 2. Average treatment effects of CRPs on accountability. (a) Horizontal accountability, (b) Vertical accountability. The shaded area depicts a 95\% confidence interval of the average treatment effects (ATEs)

To complement the fixed-effects analyses and examine whether the results are robust to unobserved confounders, Figure 2a shows the average treatment effects (ATEs) of CRPs on horizontal accountability over time using the GSC method. ${ }^{10}$ The gray area depicts the 95 per cent

\footnotetext{
${ }^{10}$ The analyses are conducted using R gsynth package (Xu 2017). Other covariates are China's flows of other categories per capita, ODA per capita, GDP per capita, GDP growth and regional average Polity scores.
} 
Table 4. Regression estimates of the effect of China's SOE development flows on institutional accountability

\begin{tabular}{|c|c|c|c|c|c|c|c|c|}
\hline DV & $\begin{array}{c}\text { Horizontal } \\
\text { accountability } \\
1\end{array}$ & $\begin{array}{c}\text { Vertical } \\
\text { accountability } \\
2\end{array}$ & $\begin{array}{c}\text { Horizontal } \\
\text { accountability } \\
3\end{array}$ & $\begin{array}{c}\text { Vertical } \\
\text { accountability } \\
4\end{array}$ & $\begin{array}{c}\text { Horizontal } \\
\text { accountability } \\
5\end{array}$ & $\begin{array}{c}\text { Vertical } \\
\text { accountability } \\
6\end{array}$ & $\begin{array}{c}\text { Horizontal } \\
\text { accountability } \\
7\end{array}$ & $\begin{array}{c}\text { Vertical } \\
\text { accountability } \\
8\end{array}$ \\
\hline $\begin{array}{l}\text { In China's SOE flows \% } \\
\text { GNI }\end{array}$ & $-0.0498^{\star \star}$ & -0.0177 & & & & & & \\
\hline (resource-related) & $(0.0222)$ & $(0.0371)$ & & & & & & \\
\hline $\begin{array}{l}\text { In China's SOE flows \% } \\
\text { GNI }\end{array}$ & -0.0199 & -0.0248 & & & & & & \\
\hline (other categories) & $(0.0492)$ & $(0.0434)$ & & & & & & \\
\hline $\begin{array}{l}\text { In China's SOE flows per } \\
\text { capita }\end{array}$ & & & $-0.0299^{\star \star \star}$ & -0.0184 & & & & \\
\hline (resource-related) & & & $(0.0113)$ & $(0.0155)$ & & & & \\
\hline $\begin{array}{l}\text { In China's SOE flows per } \\
\text { capita }\end{array}$ & & & 0.00525 & -0.00496 & & & & \\
\hline (other categories) & & & $(0.0229)$ & $(0.0142)$ & & & & \\
\hline $\begin{array}{l}\text { In China's non-SOE flows } \\
\% \mathrm{GNI}\end{array}$ & & & & & 0.0310 & 0.00948 & & \\
\hline (resource-related) & & & & & $(0.162)$ & $(0.0819)$ & & \\
\hline $\begin{array}{l}\text { In China's non-SOE flows } \\
\% \mathrm{GNI}\end{array}$ & & & & & -0.0210 & 0.0907 & & \\
\hline (other categories) & & & & & $(0.0564)$ & $(0.0591)$ & & \\
\hline $\begin{array}{l}\text { In China's non-SOE flows } \\
\text { per capita }\end{array}$ & & & & & & & -0.01000 & -0.0138 \\
\hline (resource-related) & & & & & & & $(0.0550)$ & $(0.0324)$ \\
\hline $\begin{array}{l}\text { In China's non-SOE flows } \\
\text { per capita }\end{array}$ & & & & & & & -0.0231 & 0.0202 \\
\hline (other categories) & & & & & & & $(0.0200)$ & $(0.0234)$ \\
\hline In ODA $\%$ GNI & $\begin{array}{l}0.0728^{\star \star \star} \\
(0.0266)\end{array}$ & $\begin{array}{l}0.0590 \\
(0.0396)\end{array}$ & & & $\begin{array}{l}0.0745^{\star \star \star} \\
(0.0254)\end{array}$ & $\begin{array}{l}0.0568 \\
(0.0395)\end{array}$ & & \\
\hline In ODA per capita & & & $\begin{array}{l}0.119^{\star \star \star} \\
(0.0371)\end{array}$ & $\begin{array}{l}0.0887^{\star \star} \\
(0.0440)\end{array}$ & & & $\begin{array}{l}0.119 * \star \star \\
(0.0380)\end{array}$ & $\begin{array}{l}0.0873^{\star \star} \\
(0.0440)\end{array}$ \\
\hline Regional avg. polity & $\begin{array}{l}0.0930^{\star \star \star} \\
(0.0267)\end{array}$ & $\begin{array}{l}0.115^{\star \star \star} \\
(0.0414)\end{array}$ & $\begin{array}{l}0.0855^{\star \star \star} \\
(0.0249)\end{array}$ & $\begin{array}{l}0.108^{\star \star \star} \\
(0.0412)\end{array}$ & $\begin{array}{l}0.0931^{\star \star \star} \\
(0.0271)\end{array}$ & $\begin{array}{l}0.116^{\star \star \star} \\
(0.0415)\end{array}$ & $\begin{array}{l}0.0867^{\star \star \star} \\
(0.0260)\end{array}$ & $\begin{array}{l}0.109^{\star \star \star} \\
(0.0414)\end{array}$ \\
\hline Constant & $\begin{array}{l}-0.119 \\
(0.0878)\end{array}$ & $\begin{array}{l}0.148 \\
(0.121)\end{array}$ & $\begin{array}{l}-0.405^{\star \star \star} \\
(0.142)\end{array}$ & $\begin{array}{l}-0.0468 \\
(0.166)\end{array}$ & $\begin{array}{l}-0.126 \\
(0.0886)\end{array}$ & $\begin{array}{l}0.147 \\
(0.119)\end{array}$ & $\begin{array}{l}-0.412^{\star \star \star} \\
(0.145)\end{array}$ & $\begin{array}{l}-0.0470 \\
(0.167)\end{array}$ \\
\hline Country FE & V & v & v & $\mathrm{V}$ & V & v & $\mathrm{v}$ & $\mathrm{V}$ \\
\hline Year FE & $\mathrm{v}$ & v & v & $\mathrm{v}$ & $\mathrm{v}$ & $\mathrm{v}$ & $\mathrm{v}$ & $\mathrm{v}$ \\
\hline $\mathrm{N}$ & 1,491 & 1,491 & 1,534 & 1,534 & 1,491 & 1,491 & 1,534 & 1,534 \\
\hline Countries & 137 & 137 & 139 & 139 & 137 & 137 & 139 & 139 \\
\hline Log likelihood & 378.9 & 173.4 & 335.3 & 172.5 & 373.9 & 173.8 & 326.2 & 170.0 \\
\hline adj. $R^{2}$ (within) & 0.111 & 0.133 & 0.152 & 0.147 & 0.105 & 0.133 & 0.142 & 0.145 \\
\hline
\end{tabular}

Note: all independent variables are lagged one year. Robust standard errors in brackets. ${ }^{*} p<0.1 ;{ }^{* *} p<0.05 ;{ }^{* * *} p<0.01$. 
confidence interval generated by bootstraps. The plot shows how horizontal accountability changes in recipient countries once they receive CRPs, compared with the control units. The ATE averaged over all periods is -0.2 , with a standard error of 0.052 . That is, averaged over all post-treatment periods, receiving CRPs results in a 0.2 decrease on the horizontal accountability scale in recipient countries. Figure 2(b) displays the same analyses on vertical accountability, where the estimated ATE of CRPs is not significantly different from zero. The estimates are consistent with the regression results and suggest that CRPs are associated with a statistically significant decrease in horizontal accountability, while the effects on vertical accountability are insignificant.

Finally, to further verify whether the involvement of SOEs reinforces the negative association between CRPs and horizontal accountability, in Models 1 to 4 in Table 4, both measures of CRPs and other-category assistance only take into account projects in which at least one of the implementing agencies is a Chinese SOE. The results of Models 1 to 4 are generally consistent with those shown in Tables 1-3: CRPs are negatively associated with horizontal accountability and do not have a significant influence on electoral indices, while the effects of Chinese projects in other categories, despite being implemented by SOEs, are minimal on both aspects. In Models 5-8 in Table 4, the measures of China's financial flows only incorporate projects that do not involve Chinese SOEs, and we find no significant relationships between CRPs and horizontal accountability in any of the models. Due to the high percentage of missing data on the implementing agencies for Chinese development projects, the results may not be conclusive. However, the comparison between Models 1 to 4 and Models 5 to 8 still lends some support to our theoretical argument: Chinese resource-driven assistance, particularly when delivered through SOEs, is associated with weakened horizontal institutions in recipient countries.

\section{Conclusions}

In this article, we investigate the influence of financial flows from a prominent new donor, China, on the political institutions of recipient countries. We find that China's resource-related development projects have detrimental effects on the horizontal aspect of political accountability of recipient governments, but only minimal impacts on vertical accountability. Due to data limitations, more thorough analyses on the implementing agencies or for a longer time period have not been conducted. However, the proposed relationships are robust to different model specifications and causal identification methods.

Our findings are important for at least three reasons. First, by focusing on unique Chinese strategies, the findings contribute to the literature arguing that foreign assistance has heterogeneous effects on political institutions, depending on donors' preferences, delivery mechanisms and targeted sectors. Our findings further highlight the differential effects on different institutions: some foreign flows do not substantially erode electoral regimes, but they may have negative impacts on other institutions and thus warrant more consideration from the international development community. Secondly, our findings speak to recent studies on the possibilities of autocratization, which point out the gradual concentration of power in executive branches as a common process. We argue that external factors can be conducive to such a process. Finally, some authoritarian countries have been labeled 'black knights', which are claimed to promote autocracy in other countries, but the mechanisms remain unclear. Our findings propose a possibility: China does not deliberately export autocracy to recipient countries, but the features of its resource-driven assistance lead to some negative impacts.

Our results also suggest two promising areas for future research. First, the China case illustrates that development projects in some categories are more harmful than in others. Whether assistance from other unconventional donors, particularly projects emphasizing productive activities, shows a similar pattern merits further investigation. Secondly, can traditional donors adjust their aid packages to better meet the needs of developing countries, replacing the favored 
non-interference principle? Since Chinese assistance may be helpful in economic growth, examining how to alleviate its negative impacts is an important question for future studies.

Acknowledgements. The authors wish to thank Staffan I. Lindberg, Yoshikuni Ono, Marcus Tannenberg, editors and anonymous reviewers for helpful suggestions on earlier versions of this manuscript.

Supplementary material. Data replication sets are available in Harvard Dataverse at: https://doi.org/10.7910/DVN/7FF70O and online appendices are available at https://doi.org/10.1017/S0007123420000381.

Funding. This research project was supported by the Ministry of Science and Technology of Taiwan (105-2410-H-006-107-MY2).

\section{References}

Abi-Habib M (2018) How China got Sri Lanka to cough up a port. The New York Times, 25 June. Available from https:// www.nytimes.com/2018/06/25/world/asia/china-sri-lanka-port.html.

Ahmed F (2012) The perils of unearned foreign income: aid, remittances, and government survival. American Political Science Review 106(1), 146-165.

Alden C and Alves AC (2009). China and Africa's natural resources. Occasional Paper 41. Johannesburg: South African Institute of International Affairs.

Altincekic C and Bearce D (2014) Why there should be no political foreign aid curse. World Development 64, 18-32.

Alves AC (2013) China's 'win-win' cooperation. South African Journal of International Affairs 20(2), 207-226.

Asongu S and Nwachukwu J (2016) Foreign aid and governance in Africa. International Review of Applied Economics 30(1), 69-88.

Bader J (2015a) China, autocratic patron? An empirical investigation of China as a factor in autocratic survival. International Studies Quarterly 59(1), 23-33.

Bader J (2015b) Propping up dictators? Economic cooperation from China and its impact on authoritarian persistence in party and non-party regimes. European Journal of Political Research 54(4), 655-672.

Bader J and Daxecker U (2015) A Chinese resource curse? Journal of Peace Research 52(6), 774-790.

Bermeo N (2016a) On democratic backsliding. Journal of Democracy 27(1), 5-19.

Bermeo SB (2011) Foreign aid and regime change: a role for donor intent. World Development 39(11), $2021-2031$.

Bermeo SB (2016b) Aid is not oil: donor utility, heterogeneous aid, and the aid-democratization relationship. International Organization 70(1), 1-32.

Bodea C, Garriga AC and Higashijima M (2019) Economic institutions and autocratic breakdown: monetary constraints and fiscal spending in dominant-party regimes. Journal of Politics 81(2), 601-615.

Boix C and Stokes SC (2003) Endogenous democratization. World Politics 55(4), 517-549.

Bougheas S, Demetriades P and Mamuneas T (2000) Infrastructure, specialization, and economic growth. Canadian Journal of Economics 33(2), 506-522.

Bräutigam D (2009) The Dragon's Gift: The Real Story of China in Africa. Oxford: Oxford University Press.

Bräutigam D and Knack S (2004) Foreign aid, institutions, and governance in sub-Saharan Africa. Economic Development and Cultural Change 52(2), 255-285.

Brazys S, Elkink J and Kelly G (2017) Bad neighbors? How co-located Chinese and World Bank development projects impact local corruption in Tanzania. The Review of International Organizations 12(2), 227-253.

Buckley P et al. (2007) The determinants of Chinese outward foreign direct investment. Journal of International Business Studies 38(4), 499-518.

Bueno de Mesquita B and Smith A (2010) Leader survival, revolutions, and the nature of government finance. American Journal of Political Science 54(4), 936-950.

Bun M and Harrison T (2019) OLS And IV estimation of regression models including endogenous interaction terms. Econometric Reviews 38(7), 814-827.

Bunce V and Wolchik S (2010) Defeating dictators: electoral change and stability in competitive authoritarian regimes. World Politics 62(1), 43-86.

Casey N and Krauss C (2018) It doesn't matter if Ecuador can afford this dam. China still gets paid. The New York Times, 24 December. Available from https://www.nytimes.com/2018/12/24/world/americas/ecuador-china-dam.html.

Coppedge M (2017) Eroding regimes: What, where, and when? V-Dem Working Paper 57. Gothenburg: Varieties of Democracy Institute.

Coppedge M et al. (2011) Conceptualizing and measuring democracy: a new approach. Perspectives on Politics 9(2), 247-267.

Cruz C, Keefer P and Scartascini C (2016) Database of Political Institutions 2015. Washington, DC: Inter-American Development Bank.

Dahl R (1973) Polyarchy: Participation and Opposition. New Haven, CT: Yale University Press. 
De Boef S and Keele L (2008) Taking time seriously. American Journal of Political Science 52(1), 184-200.

Démurger S (2001) Infrastructure development and economic growth: an explanation for regional disparities in China? Journal of Comparative Economics 29(1), 95-117.

Dietrich S and Wright J (2013). Foreign aid and democratic development in Africa. In Resnick D and Van de Walle N (eds), Democratic Trajectories in Africa. Oxford: Oxford University Press, pp. 56-86.

Dietrich S and Wright J (2014) Foreign aid allocation tactics and democratic change in Africa. Journal of Politics 77(1), 216-234.

Djankov S, Montalvo J and Reynal-Querol M (2008) The curse of aid. Journal of Economic Growth 13(3), 169-194.

Doucouliagos H (2019) The politics of international aid. In Congleton RD, Grofman BN and Voigt S (eds), The Oxford Handbook of Public Choice, vol. 2. Oxford: Oxford University Press, pp. 697-724.

Dreher A and Fuchs A (2015) Rogue aid? An empirical analysis of China's aid allocation. Canadian Journal of Economics 48(3), 988-1023.

Dreher A et al. (2016) Aid on demand: African leaders and the geography of China's foreign assistance. Working Paper 3. Williamsburg, VA: AidData.

Dreher A et al. (2017) Aid, China, and growth: Evidence from a new global development finance dataset. Working Paper. Williamsburg, VA: AidData.

Dreher A et al. (2018) Apples and dragon fruits. International Studies Quarterly 62(1), 182-194.

Dunning T (2004) Conditioning the effects of aid: Cold War politics, donor credibility, and democracy in Africa. International Organization 58(2), 409-423.

Erickson A (2018) Malaysia cancels two big Chinese projects, fearing they will bankrupt the country. Washington Post, 21 August. Available from https://www.washingtonpost.com/world/asia_pacific/malaysia-cancels-two-massive-chineseprojects-fearing-they-will-bankrupt-the-country/2018/08/21/2bd150e0-a515-11e8-b76b-d513a40042f6_story.html.

Esfahani HS and Ramírez MT (2003) Institutions, infrastructure, and economic growth. Journal of Development Economics 70(2), 443-477.

Finkel S, Pérez-Liñán A and Seligson M (2007) The effects of US foreign assistance on democracy building. World Politics 59(3), 404-439.

Fish S (2006) Stronger legislatures, stronger democracies. Journal of Democracy 17(1), 5-20.

Furukawa M (2018) Management of the international development aid system. Development Policy Review 36(S1), O270-O284.

Gasiorowski M (1995) Economic crisis and political regime change. American Political Science Review 89(4), 882-897.

Gerring J et al. (2005) Democracy and economic growth. World Politics 57(3), 323-364.

Gleditsch KS and Ward M (2006) Diffusion and the international context of democratization. International Organization 60(4), 911-933.

Habiyaremye A (2013) 'Angola-mode' trade deals and the awakening of African lion economies. African Development Review 25(4), 636-647.

Hodler R and Raschky P (2014) Regional favoritism. The Quarterly Journal of Economics 129(2), 995-1033.

Holland S and Wroughton L (2018) U.S. to counter China, Russia influence in Africa: Bolton. Reuters. Available from https://www.reuters.com/article/us-usa-trump-africa-idUSKBN1OC1XV.

Hout W (2007) The Politics of Aid Selectivity. Abingdon: Routledge.

Isaksson A and Kotsadam A (2018) Chinese aid and local corruption. Journal of Public Economics 159, 146-159.

Jenkins R (2010) China's global expansion and Latin America. Journal of Latin American Studies 42(4), 809-837.

Jensen N (2008) Political risk, democratic institutions, and foreign direct investment. Journal of Politics 70(4), 1040-1052.

Jensen N, Malesky E and Weymouth S (2014) Unbundling the relationship between authoritarian legislatures and political risk. British Journal of Political Science 44(3), 655-684.

Jones S and Tarp F (2016) Does foreign aid harm political institutions? Journal of Development Economics 118, $266-281$.

Kersting E and Kilby C (2014) Aid and democracy redux. European Economic Review 67, 125-143.

Kim NK and Kroeger A (2017) Rewarding the introduction of multiparty elections. European Journal of Political Economy 49, 164-181.

Knack S (2001) Aid dependence and the quality of governance: cross-country empirical tests. Southern Economic Journal 68(2), 310-330.

Knack S (2004) Does foreign aid promote democracy? International Studies Quarterly 48(1), 251-266.

Kolstad I and Wiig A (2012) What determines Chinese outward FDI? Journal of World Business 47(1), 26-34.

Kolstad I and Wiig A (2016) Does democracy reduce corruption? Democratization 23(7), 1198-1215.

Leung G, Li R and Low M (2011) Transitions in China's oil economy, 1990-2010. Eurasian Geography and Economics 52(4), 483-500.

Levitsky S and Way L (2010). Competitive Authoritarianism: Hybrid Regimes After the Cold War. Cambridge: Cambridge University Press.

Lührmann A and Lindberg SI (2019) A third wave of autocratization is here: what is new about it? Democratization 26, 1095-1113.

Lührmann A et al. (2018) State of the world 2017: autocratization and exclusion? Democratization 25(8), 1321-1340. 
Marsh J (2018) Ex-Hong Kong politician faces jail after bribery conviction in US. CNN, 6 December. Available from https:// edition.cnn.com/2018/12/05/asia/patrick-ho-bribery-conviction-intl.

Marsh J (2019) A legacy of lunacy haunts Kenya's old railway. CNN, 20 May. Available from https://edition.cnn.com/2019/ 05/20/china/china-kenya-sgr-rail-africa-intl/index.html.

Marshall M, Gurr TR and Jaggers K (2017) Polity IV Project: Political Regime Characteristics and Transitions, 1800-2016. Vienna, VA: Center for Systemic Peace.

Mawdsley E, Savage L and Kim S (2014) A 'post-aid world'? Paradigm shift in foreign aid and development cooperation at the 2011 Busan high level forum. The Geographical Journal 180(1), 27-38.

Mazzuca S (2013) Lessons from Latin America: the rise of rentier populism. Journal of Democracy 24(2), 108-122.

McMann K et al. (2019) Why low levels of democracy promote corruption and high levels diminish it. Political Research Quarterly. DOI: 10.1177/1065912919862054.

Mechkova V, Lührmann A and Lindberg SI (2017) How much democratic backsliding? Journal of Democracy 28(4), 162-169.

Mechkova V, Lührmann A and Lindberg SI (2019) The accountability sequence: from de-jure to de-facto constraints on governments. Studies in Comparative International Development 54(1), 40-70.

Miller M (2015) Electoral authoritarianism and human development. Comparative Political Studies 48(12), $1526-1562$.

Molenaers N, Dellepiane S and Faust J (2015) Political conditionality and foreign aid. World Development 75, 2-12.

Morrison K (2007) Natural resources, aid, and democratization. Public Choice 131(3-4), 365-386.

Moss T, Pettersson G and Van de Walle N (2006) An aid-institutions paradox? A review essay on aid dependency and state building in sub-Saharan Africa. Working Paper 74. Washington, DC: Center for Global Development.

Nickell S (1981) Biases in dynamic models with fixed effects. Econometrica, 1417-1426.

Nordensvard J, Urban F and Mang G (2015) Social innovation and Chinese overseas hydropower dams. Sustainable Development 23(4), 245-256.

O’Donnell G (1998) Horizontal accountability in new democracies. Journal of Democracy 9(3), 112-126.

Persson T, Roland G and Tabellini G (1997) Separation of powers and political accountability. The Quarterly Journal of Economics 112(4), 1163-1202.

Ping SN, Wang YT and Chang WT (2020) Replication Data for: The Effects of China's Development Projects on Political Accountability. https://doi.org/10.7910/DVN/7FF70O, Harvard Dataverse, V1 .

Przeworski A and Limongi F (1997) Modernization: theories and facts. World Politics 49(2), 155-183.

Ravallion M (2009) Are there lessons for Africa from China's success against poverty? World Development 2(37), 303-313.

Reinsberg B (2015) Foreign aid responses to political liberalization. World Development 75, 46-61.

Remmer K (2004) Does foreign aid promote the expansion of government? American Journal of Political Science 48(1), 77-92.

Ross M (2001) Timber Booms and Institutional Breakdown in Southeast Asia. Cambridge: Cambridge University Press.

Ross M (2015) What have we learned about the resource curse? Annual Review of Political Science 18, 239-259.

Ross M and Mahdavi P (2015). Oil and gas data, 1932-2014. Harvard Dataverse 2.

Ru H (2018) Government credit, a double-edged sword: evidence from the China development bank. The Journal of Finance 73(1), 275-316.

Schedler A (2013) The Politics of Uncertainty: Sustaining and Subverting Electoral Authoritarianism. Oxford: Oxford University Press.

Scott JM and Steele C (2011) Sponsoring democracy: the United States and democracy aid to the developing world, 19882001. International Studies Quarterly 55(1), 47-69.

Singer D, Bremer S and Stuckey J (1972) Capability distribution, uncertainty, and major power war, 1820-1965. In Russett B (ed.), Peace, War, and Numbers. Beverly Hills, CA: Sage, pp. 19-48.

State Council (PRC) (2012) China's Energy Policy 2012. Available from http://www.scio.gov.cn/zfbps/ndhf/2012/Document/ 1233788/1233788.htm.

Strange A et al. (2013) China's development finance to Africa. Center for Global Development Working Paper 323.

Treisman D (2015) Income, democracy, and leader turnover. American Journal of Political Science 59(4), 927-942.

Tull D (2006) China's engagement in Africa: scope, significance and consequences. The Journal of Modern African Studies 44(3), 459-479.

Wako HA (2018) Aid, institutions and economic growth in sub-Saharan Africa: heterogeneous donors and heterogeneous responses. Review of Development Economics 22(1), 23-44.

Wang Y and Zhao L (2017) Outward foreign direct investment from China. The Chinese Economy 50(5), 356-365.

Xu Y (2017) Generalized synthetic control method. Political Analysis 25(1), 57-76.

Cite this article: Ping S-N, Wang Y-T, Chang W-Y (2022). The Effects of China's Development Projects on Political Accountability. British Journal of Political Science 52, 65-84. https://doi.org/10.1017/S0007123420000381 